\title{
ISOLATION AND IDENTIFICATION OF PATHOGENIC BACTERIA SECRETION OF CHRONIC SUPPURATIVE OTITIS MEDIA PATIENTS
}

\author{
Suryani Suryani ${ }^{1, *}$, Zulmardi $^{2}$, Abdi Dharma ${ }^{3}$ and Nasril Nasir ${ }^{4}$ \\ ${ }^{1}$ Departement Chemistry, Muhammadiyah University of West Sumatera, Padang, Indonesia \\ ${ }^{2}$ Biology, Muhammadiyah University of West Sumatera, Padang, Indonesia \\ ${ }^{3}$ Chemistry, Andalas University, Padang, Indonesia \\ ${ }^{4}$ Biology, Andalas University, Padang, Indonesia \\ *E-mail: suryanimdiah@yahoo.com
}

\begin{abstract}
The aims of this research were to isolate and identify the pathogenic bacteria in the secretion of Chronic Suppurative Otitis Media (CSOM) patients as the development of Lactic Acid Bacteria (LAB) analysis in Virgin Coconut Oil (VCO) fermentation process. It is expected that LAB in the VCO could be antimicrobial/antibacterial of bacteria in the secretion of CSOM patients. There were 2 stages conducted within this research, firstly using blood agar and dilution method in isolating the bacteria in CSOM patients's secretion. Secondly, the isolates were identified morphologically, physiology, and another biochemical test. There are 126 isolates and 5 kinds of pathogenic bacteria(Pseudomonas aureginosa, Staphilococus aureus, Staphilococusepidermidis, Proteus mirabilis, Klebsiella $S p$ ) and one kind of fungi (Candida sp)as the result. The samples of CSOM patients are $60 \%$ above aged 20 and $40 \%$ below it, and an equal balance of percentage between male and female.

Keywords: Pathogenic bacteria isolation, Secretion of CSOM patients, Chronic Suppurative OtitisMedia, Virgin Coconut Oil (VCO), Lactic Acid Bacteria (LAB).

() RASĀYAN. All rights reserved
\end{abstract}

\section{INTRODUCTION}

Chronic Suppurative Otitis Media (CSOM) is one of the ear diseases that commonly suffered by children and causes deafness, even death ${ }^{1,2}$. It usually attacks people in developing countries such as India, Nepal, Vietnam and also Indonesia ${ }^{3,4}$. Indonesian calls it 'congek', and is one of the deadly diseases because there are tympanic membrane perforation and secretion that flows from the outer ear continuously or temporary which can cause dangerous complication such as brain abscess and meningitis ${ }^{5}$.CSOM derives from the late effect of treatment for acute otitis media patient, or poor hygiene practice, high virulence, and a weak immune system due to malnutrition ${ }^{6}$.

Some researchers have tried to isolate the pathogenic bacteria in the secretion of CSOM patients, and one of them was an Indian researcher ${ }^{7}$. He said that from 80 samples of CSOM patients, there were few pathogenic bacteria; Staphilococcus aureus, Pseudomonas sp, Escherichia coli, and Klebsiella sp.Apparently, $18 \%$ of the bacteria were resistance toward antibiotic like methicillin, and sensitive toward amikacin, chloramfenicoland piperacillin.

The most pathogenic bacteria found in CSOMthathighlighted CSOM object wereStreptococcus Pnemoneaand a virus ${ }^{1}$. those pathogenic bacteria previously mentioned were aerobic and anaerobic.P.aeruginosa, S.aureus, S. pyogenes, K.pneumoniae, H.influenzae, Bacteroides andProteus $s p$ were mostly found along with the mixture of aerobic and anaerobic bacteria that form a layer called biofilm ${ }^{8}$.

Meanwhile that there were bacteriocins in Lactid Acid Bacteria (LAB). Bacteriocins can kill pathogenic bacteria but it is safe for non-pathogenic bacteria. ${ }^{10-12}$ Antibacterial test and anti-fungal

Rasayan J. Chem., 11(3), 1139 - 1143(2018)

http://dx.doi.org/10.31788/RJC.2018.1131966

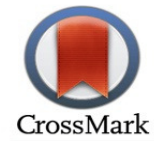


test using 5 samples of bacteria (E.coli NBRC14237, Staphylococcus aereus NBRC 13276, Bacillus substilis BTCCB, Salmonella thypii, and Listeria monocytogenes) and 2 samples of fungi (Aspergillusnigerand Candida sp) in VCO fermentation process, recently found also spices that have the ability as antimicrobial ${ }^{9,13-15}$ there were pathogenic bacteria of CSOM patients found among samples of bacteria (S. Aureus). There was a fungus of CSOM patient found between the samples ${ }^{11}$. Because the oil layer in VCO is contained LAB that can inhibit the growth of pathogenic bacteria, thus it is hoped that this bacteria in patients secretion can be inhibited as well by the LAB.

\section{Materials}

\section{EXPERIMENTAL}

Material for this study was ear liquid of 126 CSOM patients in RSUP DR. M. Jamil Padang, Indonesia Hospital. Blood and McConkey agar was the media used to grow the bacteria during conventional isolation and identification processes.

\section{Methods}

Previously, 2 stages were implemented before going through the identification process. They were by isolating the pathogenic bacteria taken from 126 CSOM patients. Then identifying them using gramnegative and positive test, bacterial staining test, morphology test, and biochemical test including catalase test and other carbohydrate tests.

\section{General Procedure}

\section{Pathogenic Bacteria Isolation in the Patients Secretion}

The bacteria identification in 126 CSOM patients secretion was begun with the isolation stage. The dilution method was taken in isolating the bacteria which was up to $10^{-7}$ dilution level, whilst the media used were blood and McConkey agar. Streaking the bacteria to form it into a single colony was done so it could become the isolate of the pathogenic bacteria. At the same time when the secretion was scratched in blood agar, it was also enriched in tiogikolat. When there was no bacterium grew in the media, then continued to enriching and planting the sample within blood agar media. Usually, in each CSOM patient, there was one isolate produced.

\section{The Identification of Pathogenic Bacteria Isolate}

Then the collected isolates were morphologically identified referred to their colony pattern and color. Besides that, positive and negative-gram tests, a biochemical tests like catalase test, starch test, and novobiocin test were also performed.

\section{RESULTS AND DISCUSSION}

Seen in the Table-1 below is the data of secretion taken from CSOM patients.

Table-1: Sample Distribution

\begin{tabular}{l|l|l|l|l}
\hline No. & Patient & $\%$ & Patient & $\%$ \\
\hline 1. & Children (under 13 year-old) & 40 & Male & 57 \\
\hline 2. & Adult & 60 & Female & 43 \\
\hline
\end{tabular}

The table above showed that $57 \%$ of the data were taken from the male. The patients chosen were $40 \%$ of children and $60 \%$ adult. Yaor, MA in his research stated that CSOM can affect children and adult $^{16,17}$. He confirmed that of 73 studied CSOM patients aged 9 to 84 -year-old, 17 of them (24\%) were children aged 9-15. The $40 \%$ number occurred for children were because of poor hygiene practice, therefore, was easily infected by the bacteria and another sideShyamala found that $70 \%$ of CSOM patients were children aged 0-20. It was similar with Moris statement that mostly those who suffer CSOM were chilren ${ }^{3,18,19}$. Accordingly, ${ }^{20}$, were children 0-10 years old 20\% .

\section{The Isolation of Pathogenic Bacteria}

This study found one kind of pathogenic bacteria of the CSOM patient in the isolation process, so there were 126 isolates gathered at the end. Compared to Suryani, and R. Shyamala ${ }^{19,21}$ study, he 
stated that each patient had one isolate; $64 \%$ of 192 samples, while $34 \%$ of them had more than one, and $5.33 \%$ of the isolated secretion produced fungi.So also with Strestha get mushrooms as much as $10,3 \%$ from 230 sample $^{22}$.

\section{Morphologic Identification of Pathogenic Bacteria}

The bacteria identification result of 126 secretions of CSOM patients can be seen in Table-2.

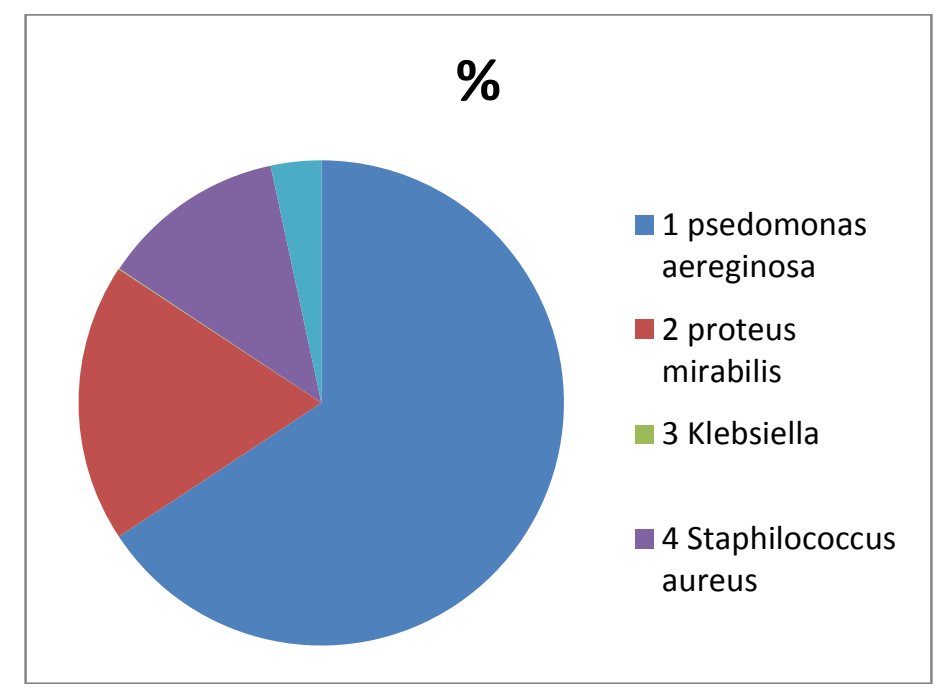

Fig.-1: Percentage of IsolatesTypesMorphology

Table-2: Isolates Morphologic Analysis

\begin{tabular}{|c|c|c|}
\hline No. & Isolate Macroscopic Characteristics & No of Isolate \\
\hline 1. & $\begin{array}{ll} & \text { Pseudomonas aureginosa } \\
\text { - } & \text { Grayish white in color } \\
\text { - } & \text { Fragment like shape } \\
\text { - } & \text { 6-15 mm in size } \\
\text { - } & \text { Rough in texture } \\
\text { - Greenish pigment } \\
\text { - Smelly } \\
\text { - Gram-negative (bacilli) }\end{array}$ & $(58,7 \%)$ \\
\hline 2. & $\begin{array}{ll} & \text { Proteus mirabilis } \\
\text { - } & \text { Circular in shape } \\
\text { - } & \text { Medium in size } \\
\text { - } & \text { Convex } \\
\text { - } & \text { Possessing flagella } \\
\text { - } & \text { Spread } \\
\text { - } & \text { Smell salty } \\
\text { - } & \text { Gram-negative (bacilli) } \\
\end{array}$ & $(16,6 \%)$ \\
\hline 3. & $\begin{array}{ll} & \text { Klebsiella } \\
\text { - } & \text { Circular in shape } \\
\text { - } & \text { Big in size } \\
\text { - } & \text { Convex } \\
\text { - } & \text { Mucoid } \\
\text { - Shiny } \\
\text { - Smooth edge } \\
\text { - } \text { Gram-negative bacilli }\end{array}$ & $(5 \%)$ \\
\hline 4. & $\begin{array}{ll} & \text { Staphylococcus aureus } \\
\text { - Circular in shape }\end{array}$ & $(11 \%)$ \\
\hline
\end{tabular}


RASĀYAN J. Chem.

Vol. 11 | No. 3 |1139 - 1143 | July - September | 2018

\begin{tabular}{|c|c|c|}
\hline & $\begin{array}{l}\text { - Slightly Convex } \\
\text { - Smooth edge } \\
\text { - } \text { Yellowish white in color } \\
\text { - } 2-5 \mathrm{~mm} \text { in size } \\
\text { - } \beta \text { hemolytic } \\
\text { - Positive-gram (cocci) } \\
\text { - } \quad \text { Grouped like grapes (Aciniform) }\end{array}$ & \\
\hline 5. & $\begin{array}{l}\text { Staphylococcus epidermidis } \\
\text { - } \text { Circular in shape } \\
\text { - Slightly Convex } \\
\text { - Smooth edge } \\
\text { - } \text { White in color } \\
\text { - Small in size } \\
\text { - Cocci } \\
\text { - Positive-gram } \\
\text { - } \text { Grouped like grapes (Aciniform) }\end{array}$ & $(3 \%)$ \\
\hline
\end{tabular}

For fungi identification, there was a colony found in the presence of hypa during the observation of the isolation process. Then, continued by gram staining test in order to obtain positivepseudohyphae as the result. Further, growing the samples in blood agar and Saboraud agar. Resulted that the colony grew in Saboraud agar instead of blood agar, in the form of circular shape, white, and slightly mucoid. The result showed in Table-3 below:

Table-3: Fungi Morphologic Analysis from Pathogenic Bacteria Isolates

\begin{tabular}{l|l|c}
\hline No. & \multicolumn{1}{|c|}{ Characteristics } & No of Isolate \\
\hline 1. & Candida $s p$ & $(4,7 \%)$ \\
& $\bullet$ Positive-gram & \\
& $\bullet$ Pseudohypha + & \\
& $\begin{array}{l}\text { - Absent growth in blood agar } \\
\text { P Circular in sabotaged media } \\
\text { and slightly mucoid whe in color, }\end{array}$ & \\
\hline
\end{tabular}

\section{Biochemical Test}

The results of isolates biochemical test can be viewed in Table-4.

Table-4: Result of Biochemical Test of the Isolates

\begin{tabular}{|c|c|c|c|c|c|c|c|}
\hline Isolates & \multicolumn{4}{|c|}{$\mathrm{T}$} & \multirow{2}{*}{$\frac{\text { s }}{\text { Novo }}$} & $\mathrm{t}$ & \\
\hline & Catalase & Gas & Coagu & lase & & \multicolumn{2}{|l|}{ biocin } \\
\hline Staphylococcus epidermidis & + & + & \multicolumn{2}{|l|}{-} & & \multicolumn{2}{|l|}{ sensitive } \\
\hline \multirow[t]{3}{*}{ Staphylococcus aureus } & + & + & + & & & sensitive & \\
\hline & \multicolumn{4}{|c|}{$\mathrm{T}$} & $\mathrm{s}$ & \multicolumn{2}{|l|}{$\mathrm{t}$} \\
\hline & TSIA & Gas & $\mathrm{H} 2 \mathrm{~S}$ & $\mathrm{SC}$ & Sulfur & Indole & Motile \\
\hline Klebsiella & $\mathrm{A} / \mathrm{A}$ & + & - & + & - & - & - \\
\hline Proteus mirabilis & $\mathrm{K} / \mathrm{A}$ & + & + & + & + & - & + \\
\hline Pseudomonas aureginosa & $\mathrm{K} / \mathrm{K}$ & + & - & + & + & - & + \\
\hline
\end{tabular}

From morphology identification result mentioned in Table-2 and 3, the shape, color, size of the colony from each isolate and also the gram test result are shown. The above result showed the types of pathogenic bacteria in CSOM patients secretion in X Hospital, they were Pseudomonas aureginosa $(58,7 \%)$, Staphilococus aureus (11\%), Staphilococusepidermidis(3\%), Proteus mirabilis $(16,6 \%)$, Klebsiela sp (5\%)and 1 fungiCandida sp (4,7\%). This result was in accordance with biochemical test result on each isolate such as Catalase, Coagulase, formed a gas, and Novobiocin test as stated in Table 4. Nevertheless, the result was in the same agreement with other experts, there 
were few differences on the pathogenic bacteria and fungi found in the secretion of CSOM patients. Sthrestha, 201122 said that pathogenic bacteria and pathogenic fungus of CSOM patients wereStaphylococcus aureus 32,2\%, Streptococcus pnemoni 6,1\%, Pseudomonas aureginosa 26,9 \%, Klebsiella sp 10,4\%, Proteus mirabilis 6,9\%, E.coli 6,9\%, fungiAspergillus sp 6,9\% Candida sp $2,6 \%$. Accordingly ${ }^{7}$, pathogenic bacteria of CSOM patient were Staphylococcus aureus 41,25\%, Eschericia coly 5\%, Klebsielapnemonia 7,5\%, Proteus sp 5\% andPseudomonas sp 37,5\%.

\section{CONCLUSION}

From the result mentioned above, it can be concluded that there were 126 isolates of pathogenic bacteria from the secretion of 96 CSOM patients. More over, by applying morphological, physical and biochemical test analysis of identification, there were 5 kinds of pathogenic bacteria found in patients secretion taken from X Hospital; Pseudomonas aeruginosa; Klebsiella, Proteus; Staphylococcus aureus; Staphilococusepidermidisand one species of fungi Candida sp.

\section{ACKNOWLEDGMENT}

This research would never be finished without help form other people, and we want to thank everybody that helped us to finish this research:

1. Director of DRPM of Ministry of Research, Technology and Higher Education of the Republic of Indonesia for the First-Year Fundamental Donation grant was given.

2. Prof. Dr. Rahmiana Zein; Post Graduate lecturer.

3. The Head of Dr. M. DjamilGeneral Hospital for the hospital facility used.

\section{REFERENCES}

1. P.N.S.,Moorthy, J. Lingaiah, S. Katari, and Nakirakanti, J. Octolaryngology Head Neck Surg., 2, 290(2013), DOI:10.423/ijohns.2013.26060

2. H.M. Massa, A.W. Cripps, D. Lehmann, MJA 191, 4(2009)

3. P. Adhikari , Braz. J. Otorhinolaryngol 75, 2007(2009), DOI:10.1590/S 1808-8694 2009000500010

4. A. Singh, R. Basu, \& A.Venkatesh, Res. Artic. Biol. Med. 4, 73(2012).

5. H. A. Asroe, D. R. Siregar, \& A. Aboet, J. Kesehat. Masy. Nas. 7, 567(2010).

6. H. Lampikosk, A. Aarnisal, J. Jero \& T. J. Kinnari, Otol. Neurotol. 33, 785(2012).

7. M. Prakash, K. Lakshm,S. Anuradha \&S. Gn, Asian J. Pharm. Clin. Res. 6, 5(2013).

8. R. Mittal. et al. J. Med. Microbiol. 64, 1103(2015), DOI:10.1099/jmm.0.000155.

9. Suryani, Abdi Dharma, Syukri Arief, N. N. Res. J. Pharm., Biol. Chem. Sci. 5, 1587(2014).

10. N. Udhayashree, D. Senbagam, B. Senthilkumar, K. Nithya and R. Gurusamy. Asian Pac. J. Trop. Biomed. 2, (2012), DOI:10.1016/S2221-1691(12)60197-X

11. Suryani, Abdi Dharma . Transylvanian Reviwer XXIV, 614(2016).

12. H. Khan, Departement Biotecnology, Massey University,Palmerstoon North, New Zealand, (2013).

13. A. Hamad, M.G.P. Mahardika, I.Yuliani and D. Hartanti, Rasayan J. Chem 10, 564 (2017), DOI:10.7324/RJC.2017.1021693

14. M.B. Karo, et al. Rasayan J. Chem., 10, 1280(2017), DOI: 10.7324/RJC.2017.1041887.

15. R. Sengodan, R. Ranjithkumar., K. Selvam and B. Chandarshekar, Rasayan J.Chem., 11, 63 (2018), DOI:10.7324./RJC.2018.1111934

16. M.A Yaor and B. Jafari, Ann. Afr. Med. 5, 24(2006).

17. Y. S. Lin, L. C. Lin, F.-P. and K. J. Lee, Tolaryngol. Head. Neck Surg., 140, 165(2009), DOI:10.1016/j.otohns.10.020.

18. A.H. Singh, R. Basu, Biology and Medicine 4, 73(2012).

19. R Shyamala and P Sreenivasulu Reddy.J. Microbiol. Biotechnol. Res., 2, 152(2012).

20. M. Yousuf, K. A. Majumder,A. Kamal and A.M. Shumon, Bangladesh Journal of Otorhinolaryngology, 17, 42(2011).

21. Suryani, A. Dharma,Y. Manjang, Jurnal Katalisator, 1, 1(2016), DOI: 10.22216/jk.vli2.1005

22. B. L. Shrestha, Nepal. J. ENT Head Neck Surg., 2, 6(2011).

[RJC-1966/2017] 